\title{
The Lives and Deaths of Zakia: How AIDS Changed African Community Theatre and Vice Versa
}

\author{
DR OLA JOHANSSON
}

This article discusses the functions of African community theatre in general, and its preventive capacity in the HIV/AIDS epidemic in particular. By delineating the parallel developments of community theatre and HIV prevention, the reciprocal needs of the practices are assessed in light of certain cases in Tanzania. This country has taken a leading position in the implementation of sustainable and locally owned theatre projects, but the challenges of the AIDS epidemic have proven so vast that the previously assumed purposes of community theatre must be called into question. Rather than being viewed as a means in itself, or a means for rapid change, community theatre is viewed as a relational means in coordinated programmes against AIDS. However, in spite of functioning as an exceptional relational agency for the most exposed cohort in the epidemic (women aged between fifteen and twenty-four), the social, gender and epidemic predicaments will persist as long as policy-makers do not fully recognize the status of young people and the capacity of community theatre.

Some phenomena are so big that they need to be made smaller to be fully comprehended. The global implications of AIDS rupture any conceptual definition and cultured imagination. It is now clear that it is the most devastating epidemic in recorded history and that it continues to plague populations in sub-Saharan Africa who struggle with extreme poverty, societal discontinuity and scanty health services. ${ }^{1}$ Yet the substance of the epidemic is found in a drop of blood, semen or even a tear. ${ }^{2}$ Reducing the epidemic to microscopic sizes, however, brings discourses into a mise-en-abyme of medical taxonomy. To grasp the practical issues of AIDS, a halfway point of view needs to be established, from which the macro statistics and micro samples coalesce in life-size interactions. Coincidentally, that perspective involves scenarios about as big as a theatrical production from a performance researcher's point of view.

In an ongoing research project on the capacity of community theatre to function as HIV prevention, I am combining performance analyses with focus-group discussions and interviews paying special attention to two rural areas of Tanzania. ${ }^{3}$ In the light of the complex pathological make-up, social secrecy and sexual taboos, I have found community theatre to be more expressive than clear-cut medical information on HIV and AIDS, more accurate than epidemiological statistics, and more relevant than scientific analyses of its causes and effects. The syndrome few talk about but most people cannot help but watch when acted out is a communicable disease primarily in the social sense of the word. Its routes of transmission are statistically estimated in vast incidence rates, 
but theatre shows just how complicated one such incidence is for affected people. ${ }^{4}$ Medical prevention research approaches the syndrome objectively, but in lack of a cure twenty-five years into the epidemic performances show how biased the impact of AIDS is, especially for young women and widows. It is more dangerous to be a housewife than a soldier in Africa. In some parts of southern Africa young women are five times more likely to contract HIV than men. ${ }^{5}$ In Tanzania, the country I will focus on here, the gender inequity is slightly less striking in statistical terms but still highly significant in real-life situations. Theatre is the mode of testimony and dissent that reveals such complex, biased and inequitable conditions on a community level and, as long as it is not fully recognized by policy-makers, community theatre will continue to fail as no other HIV prevention dare fail, to paraphrase Samuel Beckett.

In this article I will first provide a brief historical background by showing how HIV prevention schemes and community theatre projects have been developed in parallel and gradually converging trajectories, from top-heavy expert-driven campaigns to bottom-up approaches owned and run by community residents. After that it will become clear what a pivotal role theatre can play in HIV prevention. But just as the virus has an eerie ability to evade a medical solution by mutating, discrete preventive practices are insufficient in the complex epidemic. In light of past and current cases in Tanzania, I will suggest that community theatre can make a difference in an epidemic's progress only if its own modus operandi is open to culture-specific variations of the epidemic. Seen as a relational means of change, rather than a means in itself, or a means for rapid change, theatre against AIDS can be fully appreciated and applied as a participatory prevention practice in an epidemic that ultimately hinges on social interactions rather than pills or money. ${ }^{6}$

\section{The development of HIV prevention}

Why is it that people knowingly engage in sexual behaviour that could lead to a slow and painful premature death? Why do the best-intentioned attempts to stem the tide of the HIV epidemic often have so little impact? To what extent can local community mobilization contribute to a reduction in HIV transmission?

Catherine Campbell ${ }^{7}$

Catherine Campbell poses challenging questions in her acclaimed book 'Letting Them Die': How HIV/AIDS Prevention Programmes often Fail, but offers few answers. The reason for this is simply that there still are more questions to test than answers to apply on the syndrome. The major challenges concern the gap between knowledge and practice among general populations. How is it possible to prevent life-threatening behaviours among people who are aware of the risks (how HIV is transmitted), situations (where and when it happens), means (how to protect oneself) and consequences (the slow and painful death) of HIV and AIDS? The most troubling thing about this question is perhaps not that it is still unanswered, but that it took such a long time to pose to people who may hold answers. Instead of asking questions, so-called experts and aid workers for a very long time brought what they thought were answers to affected people, while it should have been the other way round all along. 
HIV prevention campaigns in sub-Saharan Africa were for a long time predicated on biomedical information and rational-choice theories pertinent to Northern societies. ${ }^{8}$ Models such as the theory of reasoned action, ${ }^{9}$ the health belief model ${ }^{10}$ and social learning theory ${ }^{11}$ are all based on generalized ideas on how individuals attain preventive conduct through cognitive, observational or behavioural skills, intended to predict positive outcomes of future decisions. The favourite methodology for the models comprises surveys conducted after certain doses of information, sometimes mixed with heuristic exercises to inculcate the achieved knowledge. In the 1980s particular risk groups' knowledge, attitude and practice (KAP studies) were mapped out, followed by a distribution of pamphlets and other mainly written material in information, education, communication (IEC) campaigns. The most renowned example in the invasion of acronyms $^{\prime 2}$ is the World Health Organization's ABC model, spelled out as abstain, be faithful, condomise.

The problem with the generic prevention models is that HIV transmissions can seldom be avoided by virtue of individual decisions or discrete behaviour. It does not really matter what you know or opt for if you do not know who your partner last had sex with and if it is considered unsuitable or even unsafe to ask about it, even if he suffers from a noticeable sexually transmitted infection and you are not in a position to say no to sex, or propose to use a contraceptive, since that would make him suspicious of whom you last had sex with, which may well be a legitimate concern as that affair may be your only chance to put food on the table for yourself and your children while your husband is away working, or looking for a job, or spending time in his nyumba ndogo ('little house', a metonym for mistress in Swahili). ${ }^{13}$ Even if this scenario - pointing to some of the most common routes of HIV transmission in subSaharan Africa today - involves stock characterization in a seemingly foreseeable plot, its preventive raison d'être cannot be boiled down to a level of individual decisionmaking in a controllable setting. Geopolitical, cultural and ethnic variations must always be taken into account as they involve gender roles in social systems that have likely developed in other places, times and circumstances than the present. This is one of the crucial challenges in HIV prevention schemes, namely the double-edged understanding of culture-historical backgrounds of various ethnic groups and, correspondingly, the way their cultures have been geographically displaced and structurally disintegrated over time. ${ }^{14}$ Some of the driving forces behind gender imbalances and generational clashes lie embedded in the historical and political discrepancies of precolonial, colonial and postcolonial times. The question is how to cope with them in a viable way today. This is, as will be clear below, where the diachronic and eclectic praxis of community theatre enters the epidemic scenario.

In the 1990 s prevention workers gradually realized that HIV and AIDS are not merely a medical, moral or behavioural challenge, but a syndrome which cuts through the cultural fabric of whole societies. Prevention programmes were thus designed to incorporate cultural underpinnings and local participation in behaviour, culture, communication (BCC) campaigns based on interactive processes and tailored messages through a variety of communication channels to effect individual as well as communal behaviour changes. In recent years community programmes have turned former objects, 
or 'target audiences', of projects into collaborating and ultimately self-reliant subjects, a 'paradigm drift', as it were, from expert information to grassroots participation. ${ }^{15}$

Hence the answer to the question of why people knowingly engage in a lifethreatening sexual behaviour has little to do with risk factors as such. Solutions must be pursued beyond abstract categories like 'knowledge', 'attitudes' and 'behaviour', which are only effects of underlying causes. The degree of risk-taking implicated in the spread of HIV relates to social groups lacking a livelihood which would allow them to make safe choices in life. The most vulnerable group, women aged between fifteen and twenty-four, is trapped in a vicious circle where the lack of resources often leads to interrupted schooling, early marriages and pregnancies, and ensuing transactional sex. ${ }^{16}$ According to the most recent statistics in Tanzania, $47.4 \%$ of all AIDS cases are unknown ${ }^{17}$ and many more women than men are tested (primarily in antenatal clinics), but the existing data nonetheless speak volumes about gender-specific susceptibilities. Among the cumulative AIDS cases in the country between 1987 and 2004, 1.6\% of males aged between fifteen and nineteen were found to be infected, while the same age cohort for females reached $4.5 \%$. Among males aged between twenty and twenty-four, $7.4 \%$ are estimated to be HIV-positive, while the rate for women is $16.5 \%{ }^{18}$ When it comes to absolute numbers of people living with HIV or AIDS in the period from 2000 to 2006, the estimated number is 40,00o for males aged between fifteen and twenty-four and 100,000 for females of the same age. The same statistics for persons aged between twenty and twenty-four indicate that 80,000 men versus 220,000 women are infected. ${ }^{19}$ A similar gender deviation is found in surveys of infections transmitted sexually, the main physical cause of HIV transmission. About twice as many AIDS cases come from married couples than single people. ${ }^{20}$ These statistics disprove previous notions about AIDS as a medical problem among certain risk groups engaged in certain risk behaviours; rather the data says that AIDS is a generalized syndrome that reveals social issues, in particular for female strata, that have been around for much longer than the epidemic and have to be coped with by means of culturally inclusive and integrated prevention schemes. Community theatre takes on a crucial place in HIV prevention with regard to the mobilization of young people, gender-balanced programmes and a communal examination of traditions through past and present cultural practices.

\section{The development of community theatre}

With the acknowledgement of local knowledge as an untapped resource for HIV prevention programmes, a mixed practice of culture-specific conflict- and problemsolving leads into the AIDS scenario: community theatre (a generic label with cognate variants such as Theatre for Development, popular theatre, theatre for change, applied theatre, social drama etc.). African community theatre, signifying a syncretic mix of traditional and contemporary modes of performance, has been used in various forms and for various purposes since precolonial times. Quite a few reports and books have been written about theatre as a developmental phenomenon. ${ }^{21}$ Some researchers hold doubts about the potential of applied theatre as an instrument for social reform, ${ }^{22}$ while others tend to be overly optimistic about its capacity to instigate social changes. ${ }^{23} \mathrm{~A}$ few 
studies have put community theatre in relation to AIDS, but they are either out of date ${ }^{24}$ or limited in scope, ${ }^{25}$ or lack epidemiological pertinence on a communal and interactive level. ${ }^{26}$ The most probing texts on theatre and AIDS have been written in the form of reports by researchers and outreach workers such as Augustin Hatar. ${ }^{27}$

In the 1960s, the decade of independence in most African countries, the socalled 'travelling-theatre movements' were deployed by university scholars aiming for cultural revitalization. ${ }^{28}$ European-style 'well-made plays' toured and became a mobile vehicle geared towards rural audiences by university-based African artists. Like most development workers at the time, however, the plays did not pay a great deal of attention to local traditions or languages, let alone the gender issues that lurked behind societal predicaments.

In a second phase, theatre projects were brought closer to their target audiences. In 1974 the Laedza Batanani movement was launched in Botswana, marking the start of so-called 'Theatre for Development'. This was also an academic project with builtin problems of involving local audiences in projects about communal challenges, but under the influence of Paulo Freire's 'pedagogy of the oppressed' project facilitators paid increasing attention to situational and political conditions. ${ }^{29}$ About the same time, the Ahmadu Bello University in Zaira, Nigeria, took on similar projects, now also inspired by Augusto Boal's 'theatre of the oppressed'. ${ }^{30}$ Artistic outreach workers dwelled amid villagers or urban squatters, composed skits and role-plays based on characters and scenarios as narrated by the locals, performed the result for them, and then invited the audience to alter the resolution of plots by way of simultaneous dramaturgy and post-performance discussions.

The development of community theatre spread across Africa via international workshops and eventually led to a third phase of community theatre, elaborated in countries such as Lesotho, Zimbabwe and Tanzania. ${ }^{31}$ At this point most of the creative and edifying modus operandi was entrusted the community subjects themselves, who participated directly in the planning and performing of the theatre. Community theatre went from being a social event to becoming a social process.

The third phase of community theatre coincides with the outbreak of the AIDS epidemic and yet it would take many years before the full potential of theatre projects would be employed in prevention programmes. When the first community-owned theatre projects were tried out in Tanzania in the 1980s, aid organizations such as WHO circulated Northern-style information and education on how the epidemic occurred, while religious organizations took care of the moral explanation of why it occurred. ${ }^{32}$ Not until the recognition of culture-specific communication in the 1990s would people's local knowledge and practices have a bearing on programmes dealing with their own predicaments.

What, then, were the advantages of community theatre? First of all it appealed to and mobilized the most susceptible epidemic cohorts, men and women aged between fifteen and twenty-four, who suddenly were wanted as aid workers in the most important projects in Africa. (When I meet youth groups, I usually tell them that they are involved with the most important job in the world and that I am visiting them to look, listen and learn.) In their formative years, youths usually also have a chance to 
alter traditional gender roles before being fashioned into normal citizens. Moreover, community theatre taps into the local traditions of ritual, dance, poetic, story-telling and dialogue-based performances, and combines these with contemporary modes of pedagogy and interactive theatre. At an initial stage of projects, groups are given funds at least for the pilot phase, including training by artistic facilitators and health-care personnel. Performance skills are then combined with analytical components like body and community mapping, a non-linguistic scrutiny of intimate and societal risk factors. Scenarios are discussed, preferably in gender-divided groups, before being rehearsed and performed in public meeting-places. This is yet another advantage with community theatre as HIV prevention, namely that young people are able to break the silence on taboo-laden issues of sexuality, sickness and death before and with audiences that have gradually become willing to ventilate their own private views in post-performance discussions. With the help of good drama instructors the plays are followed by 'joker'-led discussions as intricate as the plays themselves. With the help of good donors and local politicians the projects may even be enhanced by sustainable follow-up programmes. This is all too rare, though, and an issue that I will resume towards the end of this essay.

Hence the crucial activities of the social process are the performances which take place in public hubs such as marketplaces, schoolyards or traditional meeting grounds. The events are commonly announced with hard beats on drums accompanied by whistles, horns or shouts, which, in turn, prompt a dance that community residents can take part in. I have seen about a hundred performances in rural African settings and at almost every occasion a decent number of spectators have turned up spontaneously. After the initial dances, the theme of the theatre is announced by the group leader. The mere word ukimwi (AIDS) may scare off a fraction of the crowd, but more often it sharpens the attention of the bystanders. ${ }^{33}$ Short plays follow, resembling the comical verve in the tradition of Roman farce, commedia dell'arte, Molière and Dario Fo. The actions are based on improvisation influenced by local dialects, jokes and performance styles. When familiar characters are portrayed as villains in intrigues that everybody knows all too well, a peculiar alienation effect kicks in, which can be sensed like an uncanny echo after the roaring laughter. The conflicting emotions thus prompt the need for a communal meeting after the high-spirited events.

The worth of an effective social mobilization of key epidemic risk groups, of a culture-specific employment of prevention practices, and of a persuasive appeal to the large numbers of local residents, made community theatre a serious factor in the fight against AIDS in Tanzania and several other African countries. There are good reasons to assume that it has had at least a contributing effect in three sub-Saharan areas with epidemic declines, namely Uganda and the Tanzanian regions of Kagera and Mbeya. ${ }^{34}$ After looking at, listening to and learning from theatre groups in five African countries over the past four years, I am convinced that community theatre potentially is the most efficient form of HIV prevention for young people. I am equally convinced that it is the least efficiently used form of HIV prevention. ${ }^{35}$ This has to do not only with moneydriven non-governmental organizations, religiously myopic patrons or corrupt local politicians, but also with the theatre practitioners and researchers themselves. To clarify 
the misuse of community theatre, I wish to revisit a theatre project in Tanzania which took place in 1982 and 1983, when the third phase of community theatre was established and the first AIDS cases in the country were detected.

\section{The reproductive misfortune of Zakia}

The seminal 'Malya popular theatre project' got its name after a village in Mwanza region at the southern tip of Lake Victoria in Tanzania. It lasted for more than a year and epitomized what Penina Mlama calls the 'Tanzanian model' of popular theatre. ${ }^{36}$ What made the project unique, according to Mlama, was that (1) community members participated in all stages, from the social mobilization to the resulting follow-up actions, (2) the elements of the projects emanated not from preconceived ideas but local modes of discourse and performance, and (3) it drew on an already established national movement of dance and theatre in Tanzania. ${ }^{37}$

In her book Culture and Development (1991), Mlama opens with an intricate pan-African background to her work. Colonial history and Western capitalist contemporaneity are blamed for Africa's macro political problems, while European missionaries are liable for imposing a culture of silence through implementations of Christian doctrines onto the micro political grassroots. These ideological contraventions have had repercussions in postcolonial times through autocratic African politics as well as top-down Western development programmes. In the same breath, however, Mlama celebrates the Chinese Cultural Revolution as an exemplary social mobilization and uprising, a propagandist delusion promoted by Tanzanian authorities in Mlama's formative years as an artist. ${ }^{38}$ In order to infuse an independent spirit in Tanzanians Mlama puts faith in the ideological role of precolonial performances. This was a time when 'children [sat] by their grandmothers' feet' on 'moonlit nights' and got 'entertained and educated' by performances that served as 'a tool for instruction and transmission of knowledge, values and attitudes in initiation rites, marriage, death, religious rituals or public forums for behavioural appraisal, criticism and control'. ${ }^{39}$ With a pseudo-Brechtian stance against entertainment, Mlama argues for an ideologically conscious theatre in schools and other public institutions and spheres, but comes to the realization that Tanzanian authorities were and are rather indifferent to theatre except as a mouthpiece for the ruling party. ${ }^{40}$

The Malya project took on the burning issue of schoolgirl pregnancies with triggering factors such as poverty, male-dominated schooling, political corruption and the ensuing premature marriages, divorces and prostitution. ${ }^{41}$ It is interesting to reread Mlama's book in light of the AIDS epidemic for two reasons: first, because the first cases of AIDS-related deaths were recorded in Tanzania in the bordering Kagera region at the very time of Mlama's project ${ }^{42}$ and, second, because the project dramatized predicaments associated with social life in general and gender in particular which have later been dealt with as key epidemic risk factors. A performance that took place in 1982 about the schoolgirl Zakia, her friend Josephine and the businessman Mandanganya is a telling case in point. 
He gives her presents and Zakia agrees to meet him. Zakia takes the presents home and sneaks out to go and meet the businessman. She returns to find that her mother has discovered the gifts. Zakia lies that the gifts belong to Josephine. Josephine comes to say hello to Zakia but is reprimanded by Zakia's parents for corrupting Zakia. Then Josephine discovers that Zakia has taken away her boyfriend, so when the parents leave the two start fighting. The unemployed boys come to pacify them and offer to sell the gifts at the black market. In the next scene it is discovered that Zakia is pregnant but the businessman refuses to take responsibility. Josephine is also pregnant and is subjected to the same treatment by the businessman. Zakia's parents take Mandanganya to court but he gets away with a very light sentence because he bribes the judge. The parents are infuriated and decide to seek justice at the village council. The play ended here because this became the entry point for the post-performance discussion with the audience on the issues raised. ${ }^{43}$

The discussion that followed this performance is still going on in Tanzania twentyfive years after the event, but now with even greater urgency as it involves directly lifethreatening calamities and not 'only' enduring poverty, inequity and social alienation. However, at the time of the Malya project epidemic issues were already embedded in the scenarios, albeit tacitly. In the section cited above, Mlama mentions the unemployed boys' dealing with goods on the black market. This trade cut across the borders of Tanzania, Uganda and Kenya following a war between the former two countries and a severe economic crisis for all three countries by the end of the 1970s. The black market was operated by young males relying 'for food, drink and sexual services, on cafés, teashops, and bars, largely run by women'. ${ }^{44}$ The grim historical irony is that Zakia, after becoming pregnant and abandoned by Mandanganya, barred from her school (pregnant female pupils still get expelled without discretion) and probably driven away from home by her poor parents, quite likely ended up as a barmaid at a time when fishermen, truck drivers and racketeers carried the looming epidemic across and around Lake Victoria.

The post-performance discussion in Malya also forestalled topical debates on AIDS by relating schoolgirl pregnancies to the paradoxical stance of, on the one hand, reproaching youth for their drinking habits, bad work morals and disrespect for traditions that used to prohibit promiscuous lifestyles, and, on the other, acknowledging the failure of the community and parents to supervise the youth, let alone engage them in income-generating activities or other meaningful initiatives. ${ }^{45}$ In the early stages of the project parents thought that the girls, especially, would be corrupted by participating in the theatre. Furthermore, the village core group got into trouble with the African Inland Church, who protested against theatrical depictions counter to Christian conduct. The dispute was eventually toned down as the church admitted that the performances reflected realistic rather than sinful scenarios. A much more serious critique arose when the misbehaviour of the village leadership itself was divulged. The village chairman was forced to resign after it became known that both he 'and the secretary had been responsible for several unwanted pregnancies in the village'. ${ }^{46}$

When it comes to epidemic risk factors, two phenomena were anticipated in the Malya performance. One was the 'sugar daddy' dilemma, i.e. transactional sexual 
relations between young females and older men with cash or alluring gifts (e.g. clothes, jewellery, holidays). This still poses a widespread risk in today's AIDS epidemic. ${ }^{47}$ Another epidemic topic is corruption, a vast problem that not only conserves political pecking orders but also discriminates against people in terms of gender, class and ethnicity. The combination of poverty, corruption and traditional gender ideologies reproduces disastrous conditions for young women and men as frequently today as when AIDS broke out.

Zakia reappears everywhere I go in Tanzania twenty-five years after the Malya project, from the Kagera region on Lake Victoria near the Ugandan and Rwandan border, to the Mtwara region deep down by the country's south-eastern border with Mozambique. Confirming statistical patterns, young women are regularly depicted as sexual objects, prostitutes, scapegoats, victims and, quite literally, femme fatales. In Mangaka village (18 September 2003) I saw a performance about a businessman who seduces a secondary-school girl and convinces her to marry him. When she gets pregnant he immediately abandons her, with the outcome that she cannot go back to school or to her family and will have problems finding a new partner for future support. It is like a reincarnation of Zakia and her fate.

In Sululu village (11 September 2003) she staggers around drunk in a red dress on market day and hits unashamedly on men who happen to pass by on the barabara (main street). The performance is witnessed by a couple of hundred bystanders under a mango tree, while elders enjoy the action on a bench.

In Kenyana village (19 March 2004) she is coerced into having sex with the man who hired her as housemaid - and his two opium-smoking sons. At least half the village watches on, in company with politicians, religious leaders and schoolchildren. The postperformance discussion lasts twice as long as the theatre and ends with an agreement to collect money for schoolchildren with surviving single parents.

On the outskirts of Masasi town (17 July 2003) a bunch of spectators linger until dusk to see her put up resistance by punching her husband for leaving her and the children for days on end without enough money. At a market place in Bukoba town (30 August 2003), before a huge crowd of marketplace visitors, she gets deprived of all her property by her deceased husband's family and tries to hang herself. A neighbour saves her in the last second. A similar scenario occurs in Likokona village (19 September 2003), where she gets disinherited by her own brother, despite living in the matrilineal belt of southern Tanzania. She takes the case to court only to be double-crossed by a corrupt judge. The storyline is frighteningly similar to that of Zakia in 1982.

Mlama's vision of an ideological pan-African theatre informed by the cultural regimes of traditional societies does not promise epidemic solutions, and almost certainly involves more risk than mitigation. I will not go into detail here about the epidemic determinants of cultural practices but only point out that the precolonial order of kinship-regulated societies has waned almost everywhere in Africa by now and that the social continuity of initiation rites involving tutoring and life skills for youth are, again, often particularly detrimental to young females. ${ }^{48}$ Hence there is no given culturehistorical approach to an efficient community performance against AIDS.

Rather than pursuing a historical descent, I believe that an efficient HIV-preventive theatre should be sought on a more contemporaneous and horizontal level. To reiterate 
Campbell's question, the pressing epidemic task today is to provide a broad, feasible basis for action for those who are aware of HIV/AIDS and know what to do but do not do it. This complex dilemma goes beyond historical social regimes, generalized health models and discrete pilot projects.

\section{Towards a community theatre as a relational agency}

AIDS is a complex cultural syndrome that has forced community theatre to go beyond, on the one hand, the notion of rapid conflict-solving with target groups on specific developmental tasks and, on the other, the idea of a more basic conscientization for those directly involved with theatre. Hence AIDS challenged the culture-historical limitations of community theatre by urging it, according to veteran Theatre for Development researcher David Kerr, to focus on 'sexual issues previously thought of as taboo', 'attitudes to women and children' and 'issues of human rights and social exclusion' ${ }^{49}$ Reciprocally, once theatre practitioners recognized and counteracted the intricate epidemic challenges, they, in return, challenged the limitations of current HIV-prevention projects by bringing them out of the medical realm of white-collar instruction to the public arena of participatory practices where alternative life skills are enacted by community residents. I do not believe it is a coincidence that the two regions in Tanzania where significant decreases in AIDS prevalence trends and HIV incidence rates have been recorded have had plenty of active theatre groups involved in prevention programmes. ${ }^{50}$

It is possible to change an epidemic neither by discrete performances or projects nor with an ideological awareness per se. The epidemic challenges have brought about typological as well as functional consequences for the theatre. The typological consequence has to do with the historical trajectory of community theatre, from its didactic foundation in colonial times to its autonomous formation in postcolonial times, ${ }^{51}$ which again needs to be re-evaluated and rewritten. Sustainable self-reliance is a vital condition for groups who are fighting for free speech and the liberty of association, but the naive notion of artists as 'floating islands ${ }^{52}$ can also be an isolating factor if the task is about wider issues than the endurance of theatre groups. The functional consequence has to do with strategic objectives other than change. With associations to political 'revolution' and 'self-determination', the practice of Theatre for Development has come to define itself as an 'alternative practice', and 'the end point to this exploration of the alternative, and the "other" as an instrument of alienation and subjugation, is to seek a point of equilibrium or change'. ${ }^{53}$

The course of actions as planned and implemented in theatre against AIDS should not aim for change a priori, but rather function as an examination - a form of action research - of the conditions for people to lead healthy and constructive lives. ${ }^{54}$ Communal intervention becomes necessary in generalized epidemics (affecting $5 \%$ or more of adult populations), so it is not a matter of group dynamics as in drama-in-education, drama therapy or process drama. ${ }^{55}$ Theatre activities should bond and bridge social capital within and between groups. ${ }^{56}$ The debate about political self-determination versus donor affiliations is an old one for community theatre, as well as for civil society groups versus governmental influences. ${ }^{57}$ Discursive and economic self-reliance is, of course, important in light of colonial didacticism, academic elitism and authoritarian top-down projects, 
but once civil society groups working against the spread of HIV have been established they need to be aligned and coordinated with other prevention programmes.

Hence the argument I want to make and urge more research around has to do with a fundamental revision of the idea of an efficacious community theatre, especially as pertaining to the AIDS epidemic and cognate societal crises, by emphasizing its crucial qualities as a relational means for change, a generic nexus in local peer-education programmes and more comprehensive schemes in the public sector, rather than a means in itself, or a means for rapid change. Community theatre has all the qualifications for functioning as a 'best practice' in the epidemic and should be used as a relational agency in coordinated programmes. ${ }^{58}$ It effectively attracts the core risk groups on a voluntary basis in the most AIDS-affected societies in sub-Saharan Africa; allows them to steep their popular views through ceremonial, ritual, theatrical and pedagogical modes of performance as well as through biographically and collectively informed community analyses; and in that way meets the most urgent and taboo-laden issues head-on in performances and post-performance discussions where people, again and again, appeal to organizations and governmental authorities to consolidate actions against the depicted scenes.

Theatre is, of course, a small device in the pandemic apparatus, a petty franchise in the big AIDS business, but it is the link that can join the weakest parts of the chain of preventive measures if aligned with other related efforts. The performances I have referred to in this text have taken place in public hubs of social life, the very same places, in fact, where the virus spreads. A stone's throw from these performance grounds there is for sure a couple of schools, three or four churches, a mosque, a hospital, miscellaneous workplaces, community centres, a court building, a prison and various organizations. In most places none of these institutions or organizations invite young people's theatre groups.

When I recently revisited the twenty theatre groups that I first met in 2003 and 2004, it soon became clear that well-connected groups were still doing well (regardless of whether they were sponsored or not), while the more or less isolated groups were waning. The AIDS epidemic is still as serious as it ever has been and will remain so for many years. New generations need to be offered opportunities for participatory life skills and peer-education programmes, they need to be recruited and to recruit peers to counselling and testing centres and thereby get access to the newly introduced anti-retroviral drug therapies, and they need to be taken seriously by politicians and other stakeholders. The time for pilot projects is over and it is high time for the realization of follow-up programmes in cooperation with schools, hospitals, people living with HIV or AIDS, elders, non-governmental organizations, governmental offices and agencies, and so forth. A serious attempt is under way in Tanzania to coordinate multisectoral approaches in a nationwide District Response Initiative (DRI) organized by the Tanzania Commission for HIV/AIDS (TACAIDS), in which Community Mapping and Theatre against AIDS (COMATAA) holds a central place. ${ }^{59}$ But it is one thing to plan programmes in Dar es Salaam, and quite another to implement them in the communities. At a meeting with TACAIDS (4 September 2006) I was told that youth are represented in district committees in line with the DRI guidelines, but that their influence had not yet been evaluated. Progress is constantly made on paper, but seldom in situ. 
The lack of progress in HIV prevention is having concrete effects on the performances of theatre groups. While many groups are doing well in Kagera region, where the health-care system, youth centres and governmental agencies are working together, things are worse in Mtwara region. Some groups have simply given up; on my random revisits, villagers confirm to me that they have not taken part in theatre events for a long time, which usually indicates a general absence of prevention activities. In the village Lukuledi (24 August 2006) a group presented a 'variety show' of old-style struggle songs, poetry and speeches obviously intended for visiting political delegations and potential donors. It is interesting to see how people, with clenched fists in the air, declare war against AIDS, but never quite make it clear who the enemy of the struggle is. In the village of Mikangaula (29 August 2006) a group had performed provocative sketches about the epidemic risks of jando and unyago (initiation rites for men and women respectively) a couple of years ago; now a remaining fraction assembled just to hear what the muzungu (white person) had to offer them. I had to remind them that I am a researcher, not a donor. A group in Likokona, who sang a highly ironic shairi (poem) in 2003 about failing UNICEF promises, now (28 August 2006) put on innovative performances on the local epidemic scenario with open endings for postperformance discussions. They had apparently stopped waiting for money at a certain point and managed to finance their own activities since then. In Mpindimbi (25 August 2006) a youth group performed a metatheatrical piece about seminars that people attend but forget about as soon as they get drunk. The thematic range of these performances suggests that the community theatre in Mtwara is either vanishing or turning towards its own performative conditions of conducting HIV prevention.

By being linguistically, physically and managerially geared by the affected people themselves, community theatre comes so close to the key factors of the spread of HIV -i.e. the interpersonal scenarios of power-laden regimes captivating especially young females in imposed sexual routines - that its implementation can be seen as an action research assessment of the possibilities and limitations of HIV prevention as such. Young people in Africa know why people knowingly engage in sexual behaviours that lead to a slow and painful premature death. They also know why the best-intentioned attempts to stem the tide of the HIV epidemic often have so little impact. Soon, if they continue to be ignored and disrespected, the alienated youth will not tell us the truth any more but only mock us with a grinning death mask.

NOTES

1 In twenty-five years AIDS is estimated to have killed about twenty-five million people and infected sixty-five million; thus nearly forty million are currently living with the virus. (UNAIDS/WHO, 'Report on the Global AIDS Epidemic' (Geneva, available at http://www.unaids.org; accessed May 2006). As Nugent points out (with reference to R. Shell, 'Halfway to the Holocaust: The Economic, Demographic, and Social Implications of the AIDS Pandemic to the year 2010 in the Southern African Region', in R. Shell et al., eds., HIV/AIDS: A Threat to the African Renaissance (Johannesburg: Konrad Adenauer Stiftung, 2000), p. 10), 'It is estimated that by 2010, AIDS will have killed more people than all of the previous global pandemics - including the Black Death, smallpox in the sixteenth century and 
the devastating 1917/19 influenza outbreak - combined.' (P. Nugent, Africa since Independence: A Comparative History (New York: Palgrave McMillan, 2004), pp. 357-58). Tears do not transmit the virus but has a certain viral load, just like other bodily fluids. See H. Jackson, AIDS Africa: Continent in Crisis, (Harare: SAfAIDS, 2002).

3 My research project, called 'AIDS and the Art of Survival: African Community Theatre as HIV Prevention' (2003-7), is supported by the Swedish International Development and Cooperation Agency.

4 Epidemiological surveys establish the incidence (number of new cases) and prevalence (all existing cases) of morbidity of certain diseases or conditions.

5 UNAIDS/WHO, 'Report on the global AIDS epidemic'.

6 Needless to say, monetary and clinical approaches to AIDS are necessary complements to preventive measures through human resources. It is just that money and pills have for long overshadowed the cultural factors in the expertise of the epidemic. Anti-retroviral medicines have been distributed en masse by WHO in a global scheme called ' 3 in 5 ' - alluding to the ambition to reach three million people in five years - but they keep missing their goals even in areas for which they have secured funding and medical supplies. The incidence rates simply exceed the logistical possibilities of distributing medicine in many countries.

7 C. Campbell, 'Letting them Die': How HIV/AIDS Prevention Programmes often Fail (Oxford: James Currey, 2003) p. 183.

8 S. Freudenthal, 'A Review of Social Science Research on Hiv/Aids' (Stockholm: SIDA, 2002).

9 I. Ajzen, Understanding the Attitudes and Predicting Social Behaviour (Englewood Cliffs, NJ: Prentice-Hall, Inc., 1980).

10 M. Conner and P. Norman, Predicting Health Behaviour: Search and Practice with Social Cognition Models (Open University Press: Ballmore, Buckingham, 1996).

11 J. E. Ormrod, Human Learning (Upper Saddle River, NJ: Prentice-Hall, 1999).

12 P. Nugent, Africa since Independence, chap. 8.

13 Writing from a female perspective of course involves certain ethical risks, not only about being taken as a white man who wants to save brown women from brown men, as G. C. Spivak puts it ('Can the Subaltern Speak?', in Cary Nelson and Lawrence Grossberg, eds., Marxism and the Interpretation of Culture (Urbana: University of Illinois Press, 1988), pp. 271-313), but also due to the epistemological risk of alienating men in an epidemic which is ultimately about establishing gender-balanced negotiations and solutions. Nonetheless, according to statistical data, general research, my own performance analyses, focus-group discussions and interviews (see below), it is undeniable that the most critical risk factors and perilous experiences of the epidemic are female.

14 T. Barnett and A. Whiteside, AIDS in the 21st Century: Disease and Globalisation (London: Palgrave McMillan, 2002), chap. 5.

15 Campbell, 'Letting them Die', p. 9.

16 UNAIDS/WHO, 'Report on the global AIDS epidemic'.

17 Ministry of Health, 'HIV/AIDS/STD Surveillance Report' (The United Republic of Tanzania: National AIDS Control Programme, October 2005), p. 2.

18 Ibid., p. 3.

19 Ibid., p. 45.

20 Ibid., p. 6. It is important to clarify that the links between gender trouble, sexually transmitted diseases (STDs) and epidemics are not African (cf. S. Arnfred, ed., Re-thinking Sexualities in Africa (Uppsala: Almqvist and Wiksell, 2004)). The situation was very much the same in a country like Sweden. Epidemiological research about the turn of the last century shows that female employees at public institutions in Sweden had to take precautions moving about in public spheres because of the risk of being sexually abused (B. Holmdahl, Människovård och människosyn: Om omvårdnad i Uppsala före år 1900 (Uppsala: serien Uppsalas historia, Vol. VI: 7, 1988). Statistical data of STDs such as syphilis show 
comparable circumstances between Sweden then and the developing world today, indicating socio-economic underpinnings as the basis for secondary risk factors.

21 M. Pompêo Nogueira, 'Theatre for Development: An Overview', Research in Drama Education, 7, 1 (2002), pp. NN-NN; D. Kerr, African Popular Theatre: From Pre-colonial Times to the Present Day (Nairobi: East African Educational Publishers, 1995); J. Bakari and G. Materego, Sanaa kwa Maendeleo: Stadi, Mbinu na Mazoezi (Dar es Salaam: Amana Publishers, 1995); Z. Mda, When People Play People (London: ZED Books Ltd, 1993); P. Mlama, Culture and Development (Uppsala: Nordiska Afrikainstitutet, 1991); C. Kamlongera, Theatre for Development in Africa with Case Studies from Malawi and Zambia (Bonn: German Foundation for International Development, 1989); R. Kidd, From People's Theatre for Revolution to Popular Theatre for Reconstruction: Diary of a Zimbabwean Workshop, The Hague/Toronto: CESO, 1984), to mention but a few

D. Kerr, 'Art as Tool, Weapon or Shield? Arts for Development Seminar, Harare', in Biodun Jeyifo, ed., Modern African Drama (New York: W. W. Norton and Co., 2002); D. Byam, Community in Motion: Theatre for Development in Africa (Westport, CT: Bergin and Garvey, 1999); J. Plastow, African Theatre and Politics: The Evolution of Theatre in Ethiopia, Tanzania and Zimbabwe. A Comparative Study (Amsterdam: Editions Rodopi, B.V., 1996).

23 O. Abah, 'Creativity, Participation and Change in Theatre for Development Practice', in Francis Harding, ed., The Performance Arts in Africa: A Reader (New York and London: Routledge, 2002), pp. $158-73$.

24 M. Frank, AIDS Education through Theatre: Case Studies from Uganda (Bayreuth: Bayreuth African Studies, 1995).

25 R. Mabala et. al., Participatory Action Research on HIV/AIDS through a Popular Theatre Approach in Tanzania (Unicef: Evaluation and Program Planning, 2002); M. Klink, 'Theatre for Development', in Hands On! A Manual for Working with Youth on SRH (GTZ: 200o) (available at http://www2.unescobkk.org/hivaids/FullTextDB/aspUploadFiles/HandsOnPublikation.pdf; accessed 28-10-2006)

L. Bourgault, Playing for Life: Performance in Africa in the Age of AIDS (Durham, NC: Carolina Academic Press, 2003).

27 A. Hatar, Theatising AIDS for Paralegal Organisations (Dar es Salaam: Friedrich Ebert Foundation, 2001); A. Hatar, 'Theatising AIDS in Local Communities' (unpublished, 1998).

28 B. Crow and M. Etherton, 'Popular Drama and Popular Analysis in Africa', in R. Kidd and N. Colletta, eds., Tradition for Development: Indigenous Structures and Folk Media in Non-formal Education (Bonn: German Foundation for International Development, 1982). Kidd, From People's Theatre; P. Freire, Pedagogy of the oppressed (New York: Herder and Herder, 1970). O. Abah and M. Etherton, 'The Samaru Projects: Street Theatre in Northern Nigeria', Theatre Research International, 7 (1983), pp. 222-34; O. Abah and S. Balewa, The Bomo Project (Zaria, Nigeria: English Department, Ahmadu Bello University, 1982); A. Boal, Theatre of the Oppressed, trans. Charles A. and Maria-Odilia Leal McBride (London: Pluto Press, 1979).

31 Mda, When People Play People; Byam, Community in Motion, chap. 3; P. Mlama, Culture and Development, chaps 4-5; F. P. Nyoni, 'Conformity and Change: Tanzanian Rural Theatre and Socio-political Changes’ (doctoral dissertation, University of Leeds, 1998).

32 J. Iliffe, The African AIDS Epidemic: A History (Oxford: James Currey, 2006), p. 90.

33 In a Tanzanian village called Ijumbe in 2004 it was remarkable to see almost all male spectators, after enjoying an ngoma (dance), turn around and go back to their market stands as they heard the opening stanza of a choir on AIDS.

34 Frank, AIDS Education through Theatre; G. Kwesigabo, Trends of HIV infection in the Kagera Region of Tanzania (Umeå University Medical Dissertations, New Series No 710, 2001); B. Jordan-Harder, 'Thirteen Years of HIV-1 Sentinel Surveillance and Indicators for Behavioural Change Suggest Impact of Programme Activities in south-west Tanzania', AIDS, 18 (2004), pp. 287-94. 
I have no direct part in the theatre activities I am analysing and comparing, but in fact try to minimize the reactive effects of my presence among the informants. This matter is, of course, worthy of an article in its own right and cannot be exhausted here. I should add, however, that I am a teacher in community theatre at Lancaster University and that I may engage in more direct action research in the near future in Tanzania, although not as artistic trainer but as 'operational' researcher and assessor. Mlama, Culture and Development, chap. 7.

37 Ibid., pp. 95-6.

38 Ibid., p. 11, 24.

39 Ibid., pp. 26-7.

$40 \quad$ Ibid., p. 103. Femi Osofisan (in R. Boon and J. Plastow, eds., Theatre Matters: Performance and Culture on the World Stage (Cambridge: Cambridge University Press, 1998), pp. 11-35) considers students and other educated cohorts the most important target groups for radical theatre, rather than the proletariat favoured by, e.g., Ngugi wa Thiong'o and most other developmental theatre artists and groups in Africa. There are countless school projects involving theatre against AIDS in Africa, but they are mostly temporary and lack financial, administrative and moral support. It is not uncommon that teachers have sex with students, while being reluctant towards sexual and reproductive schooling due to its encouragement of promiscuous lifestyles. For country-specific views on theatre as education see also S. Lange, Managing Modernity: Gender, State, and Nation in the Popular Drama of Dar es Salaam, Tanzania (University of Bergen: Department of Social Anthropology, 2002); L. Edmondson, 'National Erotica: The Politics of “Traditional” Dance in Tanzania', Drama Review, 45, 1/T 169 (2001), pp. 153-70; T. Riccio, 'Tanzanian Theatre: From Marx to the Marketplace', Drama Review, Vol. 45, 1/T 169 (2001), pp. 128-52; Hatar, Theatising AIDS for Paralegal Organisations.

The artistic extension workers were Amandina Lihamba, Penina Mlama and Eberhard Chambulikazi, all from the University of Dar es Salaam, Tanzania.

Iliffe, The African AIDS Epidemic, p. 23; J. Iliffe, East African Doctors: A History of the Modern Profession (Cambridge: Cambridge University Press, 1998), pp. 223-4.

43 Mlama, Culture and Development, p. 118.

44 J. Appleton, “'At My Age I Should Be Sitting under that Tree”: The Impact of AIDS on Tanzanian Lakeshore Communities', Gender and Development, 8, 2 (2000), pp. 19-27, quoted in Iliffe The African AIDS Epidemic, p. 23.

45 Mlama, Culture and Development, pp. 119-20.

46 Ibid., p. 125.

47 Besides the numerous plays, a few interesting films also have depicted sugar daddies, such as the Tanzanian film Duara (2003), collectively written by students at the Fine and Performing Arts Department, University of Dar es Salaam, and directed by Richard Ndunguru.

48 For a comparative discussion on the social functions of ritual and theatre with regard to the AIDS epidemic see my 'Performative Interventions: African Community Theatre in the Age of AIDS', in Mark Franko, ed., Ritual and Event: Interdisciplinary Perspectives (London and New York: Routledge, 2006), pp. NN-NN.

49 M. Banham, ed., A History of Theatre in Africa (Cambridge: Cambridge University Press, 2004), p. 305.

$50 \quad$ Kwesigabo, Trends of HIV Infection in the Kagera Region of Tanzania; Jordan-Harder, 'Thirteen years HIV-1 Sentinel Surveillance'.

51 Kidd, From People's Theatre, p. 8.

52 E. Barba, Beyond the Floating Islands (New York: Performing Arts Journal Publications, 1986).

53 Kidd, From People's Theatre; K. Salhi, African Theatre for Development: Art for Self-Determination (Exeter: Intellect, 1998); Abah, 'Creativity, Participation and Change'.

54 Cf. J. Thompson, Applied Theatre: Bewilderment and Beyond (Oxford and Bern: Peter Lang, 2003), chap. 4. I agree with epidemiologist Hans Rosling at Karolinska Institutet in Stockholm, Sweden, that health is the best measurement of a good life, even though the concept is packed with economic, ethical 
and political issues. Health is, perhaps, the most telling angle of approach towards an assessment of worthy ways of living.

55 A. Simpson and B. Heap, Process Drama: A Way of Changing Attitudes (Stockholm: Save the Children, 2002).

56 Campbell, 'Letting them Die', pp. 55-8; R. Putnam, Bowling Alone: The Collapse and Revival of American Community (New York: Simon Schuster, 2000).

57 Kerr, 'Art as Tool, Weapon or Shield?'; D. Kerr, African Popular Theatre; N. Kasfir, ed., Civil Society and Democracy in Africa: Critical Perspectives (London: Frank Cass, 1998).

58 Bunmi Makinwa and Mary O'Grady, eds., FHI/UNAIDS Best Practices in HIV/AIDS Prevention Collection. This collection is revised continually, with reference to the following five criteria in HIV/AIDS programmes: effectiveness, ethical soundness, relevance, sustainability, and efficiency/ cost-effectiveness (see http://www.fhi.org/NR/rdonlyres/em3hz6h26apfca361cm2qvv5ewgexblrlzy6b2tr7igba2u2kuemsf4edbz7b3jamukq4n6oz4wllm/FHIUNAIDSBestPracticesredux.pdf; accessed 28-10-2006).

59 W. M. S. Muzzuki, 'National Response to HIV/AIDS', presentation at a UNAIDS conference (Arusha, Tanzania, 2002).

DR OLA JOH ANSSON, has a double assignment, namely as Lecturer in Radical Theatre and Performance Analysis at Lancaster Institute for the Contemporary Arts, and as Research Associate at Stockholm University (Sweden)/University of Dar es Salaam (Tanzania) in connection with a research project called AIDS and the Art of Survival: African Community Theatre as HIV Prevention (2006-8). His latest article is 'Performative Interventions: African Community Theatre in the Age of AIDS', in Mark Franko, ed., Ritual and Event: Interdisciplinary Perspectives (New York and London: Routledge, 2006). 